INTERNATIONAL DESIGN CONFERENCE - DESIGN 2018

https://doi.org/10.21278/idc.2018.0305

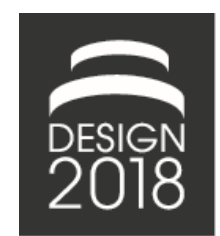

\title{
ANALYSIS OF ECODESIGN AND SUSTAINABLE DESIGN IN HIGHER EDUCATION
}

\author{
D. Kattwinkel, Y.-W. Song and B. Bender
}

\begin{abstract}
To respond to environmental sustainability challenges, many industries request that future engineers need to be sensitized and educated in the context of sustainability. This paper analyses if today's courses and degree programs meet these expectations by examining the curricula of 120 German and 50 international higher education institutions in the field of engineering. At first, it was investigated, if these institutions offer courses and degree programs covering Ecodesign and Sustainable Design, then it was analysed which specific topics and life cycle phases those courses address.
\end{abstract}

Keywords: sustainable design, ecodesign, product lifecycle, design education, curriculum

\section{Introduction}

In 1987, the World Commission on Environment and Development proposed "a global agenda for change" to achieve a sustainable development through long-term and future-oriented environmental strategies (United Nations, 1987). "Sustainable solutions are products, services, hybrids or system changes that minimize negative and maximize positive sustainability impacts - economic, environmental, social and ethical - throughout and beyond the life-cycle of existing products or solutions, while fulfilling acceptable societal demands/needs" as Charter and Tischner (2001) defined Ecodesign. The key aspect of Ecodesign is the integration of environmental considerations in the product development (Karlsson and Luttropp, 2006). In this context, the role of product developers is of vital importance. Within his field of activity, the developer significantly influences the environmental impacts of future products. During the development process, a product's function, its operating principles, shape and material are determined and with that, the most prevailing technical, economical as well as ecological product properties are specified. To consider and to improve the environmental product properties early in the development is the starting point for a purposeful and efficient development of sustainable products (Oberender, 2006). Until now, most approaches focus on the life cycle phases material production, manufacturing or recycling. However, especially the usage phase offers a significant potential for sustainable improvements, which is currently not fully exploited. For many technical products the usage phase is the most impacting of the life cycle phases. A refrigerator, for example spends up to $90 \%$ of its primary energy consumption and about $84 \%$ of its overall environmental impacts during its usage (Ruedenauer, 2006; Ma et al., 2012).

Over the past 20 years, hundreds of Ecodesign tools (e.g. GaBi) and methods (e.g. Eco-FMEA) have been developed, predominantly in academia. Their effective use and application within companies is however often not validated (Rossi et al., 2016). While the principle of ecological product design has been a topic in numerous companies, often it has not yet permeated as an integral part of the product development (Graulich et al., 2017). Even though several authors identified the development of sustainable products as a central requirement to sustain and increase a company's competitive position 
(Schäfer and Apostolov, 2014). Within the Sustainable Design Special Interest Group (SIG) workshop at ICED 2017 in Vancouver, several issues regarding the knowledge dissemination on sustainable design were pointed out by the participants (around 40 researchers in the field of sustainable design). One of the identified points was that "Educating students (on sustainable issues) seems to be more promising than changing industrial habits" (Pigosso and Leroy, 2017). So, a key success factor for the integration of Ecodesign into the product development practice is the development of competences among employees and designers through training and education (Johansson, 2002). Thus, the education of product developers and engineers faces new challenges. The change in fields of activities and requirements must be met by adapted educational concepts, that are attractive for students as well as for the industry (Albers et al., 2012). Allenby (2009) even proclaims "the combination of [...] unpredictability, complexity, and accelerating change, the interactions of emerging technologies with younger subpopulations, and the demands, however inchoate, of sustainability present a rapidly approaching and inadequately appreciated crisis in education".

Within this publication we analysed, if today's courses and degree programs meet these expectations, regarding the required sustainability focus by answering the following research questions:

- Are courses and degree programs covering Ecodesign and sustainable design in the field of engineering offered in German and international higher education institutions?

- Which specific topics are addressed in those courses relating to Ecodesign and sustainable design in German and international higher education institutions?

Following the Design Research Methodology by Blessing and Chakrabati (2009), in the Research Clarification stage, the relevant disciplines and research areas described and required terms are defined to specify the research focus and goals (Section 2). In the Descriptive Study I, a comprehensive literature and web-based research is conducted to identify courses and degree programs thematising Ecodesign and sustainable design within higher engineering education (Section 3). In the Prescriptive Study, the courses are evaluated regarding their specific content and their coverage of individual life cycle phases (Section 4). Finally, the results are discussed, and deficiencies are pointed out (Section 5).

\section{Ecodesign and sustainable development}

To examine the dispersion and application of Ecodesign and sustainable design in higher engineering education, the basic terminology (Sections 2.1) as well as relevant concepts such as the product life cycle (Section 2.2) and especially the usage phase (Section 2.3) must be described and differentiated.

\subsection{Definition of sustainable design and Ecodesign}

Until now, no uniform definition on sustainable development (SD) exists. It is merely understood to be a vague concept that focuses on sustainability at a societal level, whereas sustainable production and consumption also contribute to a broader SD framework on a strategic, operational and product level. Sustainable Design considers social, environmental and economic aspects during the design process of products and services to support SD (Verhulst and van Doorsselaer, 2015). Within this publication, sustainable design is understood to add the environmental and social dimension to the conventional dimensions of product development such as economic, functional, safety etc. (Charter and Tischner, 2001). Ecodesign, a sub-discipline within sustainable design, focuses on the environmental and economic product properties and only marginally includes the social dimension (Verhulst and van Doorsselaer, 2015). According to DIN EN ISO 14006 (DIN EN ISO, 2011), Ecodesign is defined as the "integration of environmental aspects into product design and development, with the aim of reducing adverse environmental impacts throughout a product's lifecycle".

\subsection{The product life cycle}

Product development can classically be divided into four phases, named Clarification of the task, Conceptual design, Embodiment design and Detail design (VDI, 1993). Traditionally, the manufacturing phase of the product follows the detail design. Within the development phases, all processes in the actual life cycle of the product must be defined and anticipated (see Figure 1). So, the product developer must foresee the downstream process chain of the product life cycle and its phases to 
develop products meeting all explicit and implicit requirements. This extensive knowledge is especially important when developing sustainable products (Oberender, 2006). For different research disciplines, various definitions of the product life cycle exist. A broad agreement has been established over the main phases, being Material production, Manufacturing, Usage, Recycling and Disposal (Grüner, 2001).

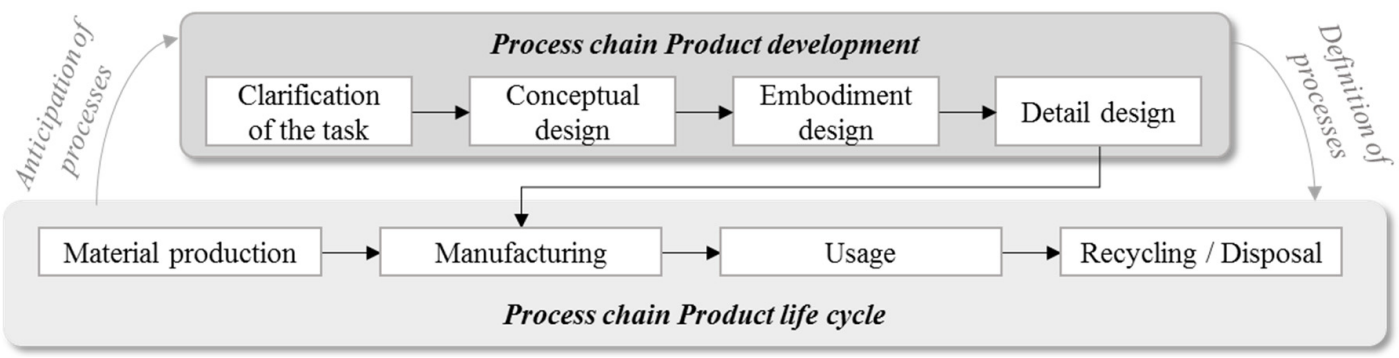

Figure 1. Product development and product life cycle (based on Abele et al., 2008)

\subsection{The product usage phase}

Even though Ecodesign is by now a significant research topic, most scientific approaches as well as methods and tools focus the life cycle phases material production, manufacturing, recycling and disposal. The directive 2009/125/EC, a European framework for the setting of Ecodesign requirements for energy-related products is the first guideline that explicitly takes the resource consumption of products during their usage into account (The European Parliament and the Council of the European Union, 2009). In addition, the concept of Product-Service Systems, life cycle costing or optimisations of the life expectancy especially target the product usage (Oberender, 2006).

But especially the use phase of technical products offers a high potential for environmental improvements, because according to Dannheim (1999) most of the environmental impacts during the life cycle accumulate during a product's usage (for household appliances up to 95\%). In addition, the sub-processes during the usage phase also influence processes in previous and subsequent life cycle phases (see Figure 1). An inappropriate usage for example may lead to an accelerated product disposal. Figure 2 illustrates the effects of product development and product usage on the environment, people and society. So, the development and usage (socio-technical systems) of new technologies or products (technical systems) do not exist independently, but have specific impacts on the ecosystem, the society and humanity (Ropohl, 2009).

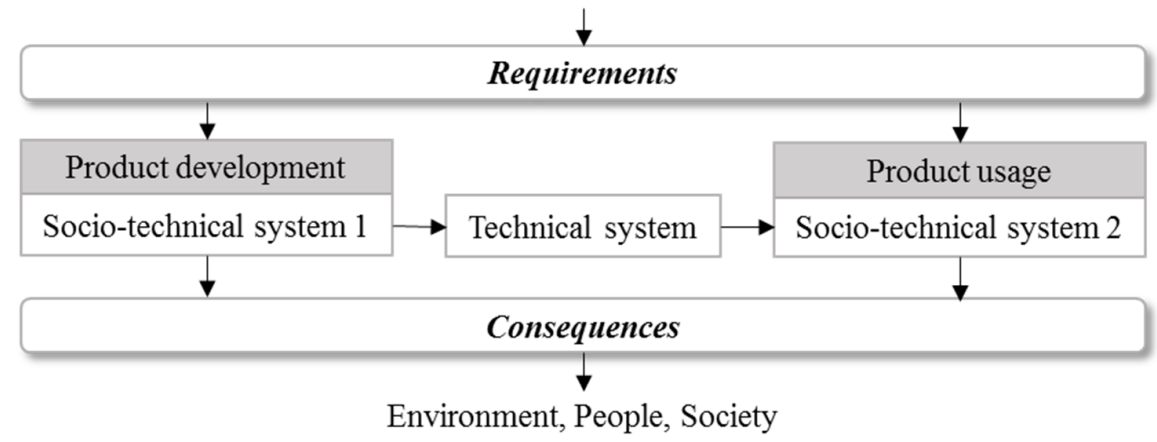

Figure 2. Effects of product development and usage (based on Ropohl, 2009)

\section{Range of sustainable and Ecodesign courses at higher education institutions}

Because Ecodesign has been identified as a promising approach "that can support and strengthen the knowledge, skills and attitude of students in higher education" (Verhulst and van Doorselaer, 2015), it is essential to examine, if Ecodesign or related topics are currently incorporated in higher education courses and degree programs not only in Germany but also in other countries. First, the approach for a literature research, material and method are explained (Section 3.1), then the results are described (Section 3.2) and an initial conclusion is drawn (Section 3.2). 


\subsection{Material and method}

To identify the courses emphasizing sustainable topics within an engineering context, the curricula of German and international higher education institutions were manually examined by the authors. From a list of all German universities and universities of applied science (Ger: Fachhochschulen), 120 institutions with a technical focus that allow a university degree in the field of engineering only (B.Sc., M.Sc., B.Eng., M.Eng.) were extracted (Bohlken, 2017a, 2017b) (see Figure 3).

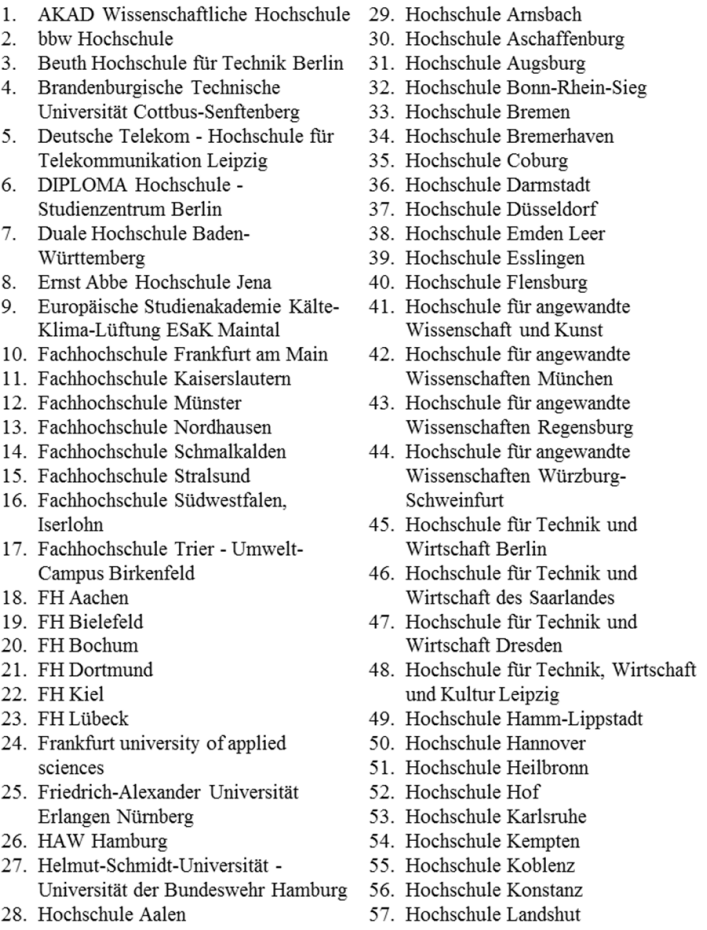
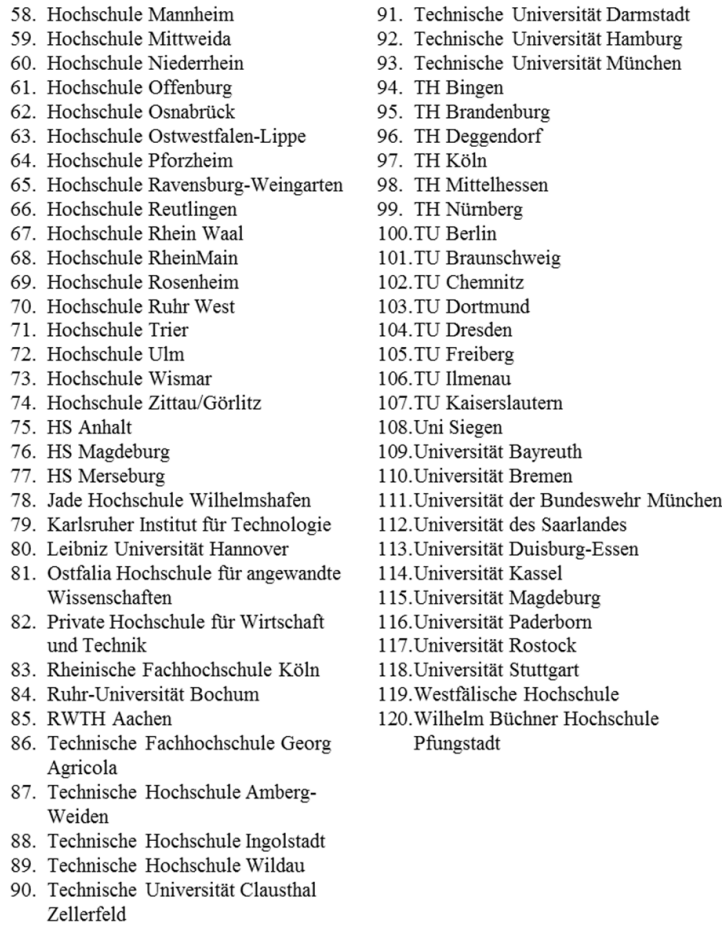

Figure 3. List of German higher education institutions (Bohlken, 2017a, 2017b)

For the analysis of international courses and degree programs, the best 50 higher education institutions from all over the world for mechanical engineering were selected (Quacquarelli Symongs Limited, 2016) (see Figure 4).

On the websites of those German and international institutions, the degree descriptions, course catalogues and module manuals of all bachelor, master, mandatory and optional courses were analysed to either identify a sustainable, environmental, eco-relevant or green degree program in the field of engineering or to find corresponding courses from mechanical, industrial or related engineering topics (e.g. aeronautical engineering).

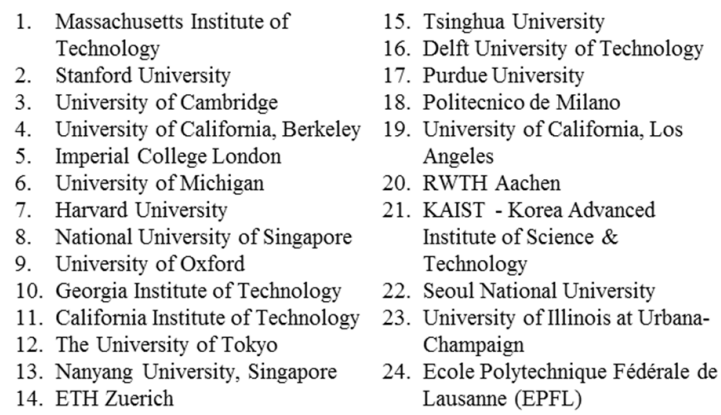

25. KTH Royal Institute of
Technology
26. Northwestern University
27. Technical University of Munich
28. Kyoto University
29. Peking University
30. The University of Melbourne
31. Shanghai Jiao Tong University
32. Tokyo Institute of Technology
33. Cornell University
34. The University of New South
Wales (UNSW Sydney)
35. Princeton University
36. Cranfield University
37. The University of Sydney

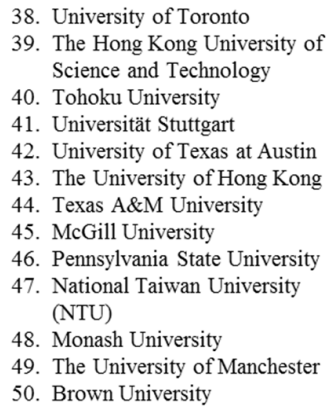

50. Brown University

Figure 4. List of international higher education institutions (Quacquarelli Symongs Limited, 2016) 


\subsection{Results of the analysis}

Based on the content of the module manuals, the handbooks and descriptions on the websites of the universities, the authors examined the courses and the degree programs regarding their subject matter. The results of the conducted analysis are illustrated in Figure 5 and 6. From the 120 German / 50 international higher education institution only $118 / 47$ curricula could be analysed, because of insufficient information.

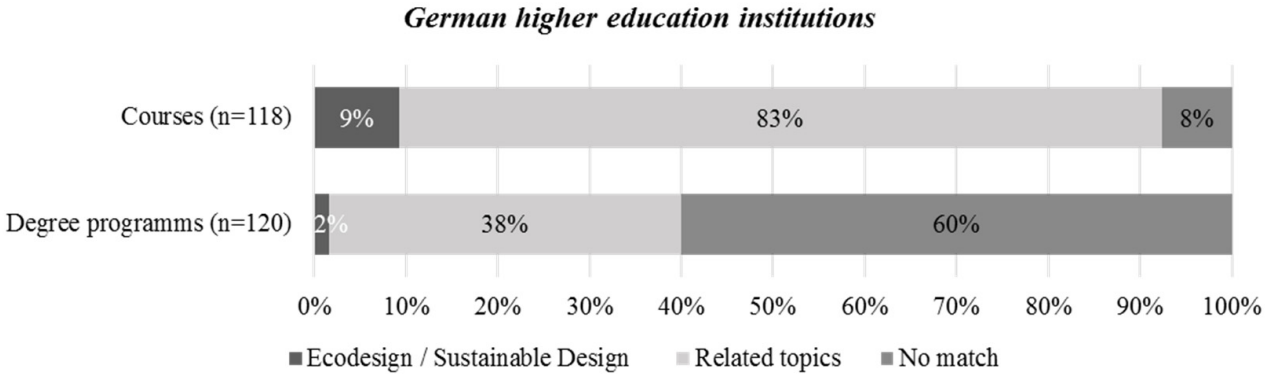

Figure 5. Analysis of German courses and degree programs

The courses that had a very high conformity with the topics Ecodesign and sustainable design are for example, Ergonomics and Ecodesign (Hochschule Aalen, Germany), Resource-efficient Product Development (Technical University Clausthal Zellerfeld, Germany), Sustainable Engineering and Design (University of Michigan, USA) and Engineering Design for Sustainable Development (Princeton University, USA). In Germany only $9 \%$ of the universities offer courses targeting sustainable or environmental engineering topics, that have such a high conformity with Ecodesign and sustainable design (see Figure 5). Internationally, $13 \%$ of the analysed curricula targeted those topics (see Figure 6). For degree programs, the percentages are even lower. In Germany, only the following programs are offered, Sustainable Engineering Science (Hochschule Bonn-Rhein Sieg) and Resource Efficiency in Mechanical Engineering (Hochschule Esslingen). On an international level, no sustainable engineering or Ecodesign degree programs were found. This may result from the fact, that only a subset of all existing international universities for mechanical engineering were analysed (see Figure 4).

The majority of German (83\%) and international (81\%) higher education institutions offer engineering courses or degree programs concerning topics related to Ecodesign and Sustainable Design or other environmental or green engineering subjects such as Sustainability and Social Justice (Stanford University, USA), Lightweight Design (Tsinghua University, China), Innovative and Energy Efficient Electric Drives for Railway Systems (University of Applied Sciences Brandenburg, Germany), Lean Production (Hochschule Ansbach, Germany), Sustainable Transport (Imperial Collage London, UK), Energy Efficiency (Delft University of Technology, Netherlands), Environmental Engineering (The HongKong University of Science and Technology, China), Integrated Environmental Protection (Technical University Hamburg, Germany), Renewable Energies (Ruhr-Universität Bochum, Germany), or Circular Economy and Disposal (Brandenburg University of Technology CottbusSenftenberg, Germany).

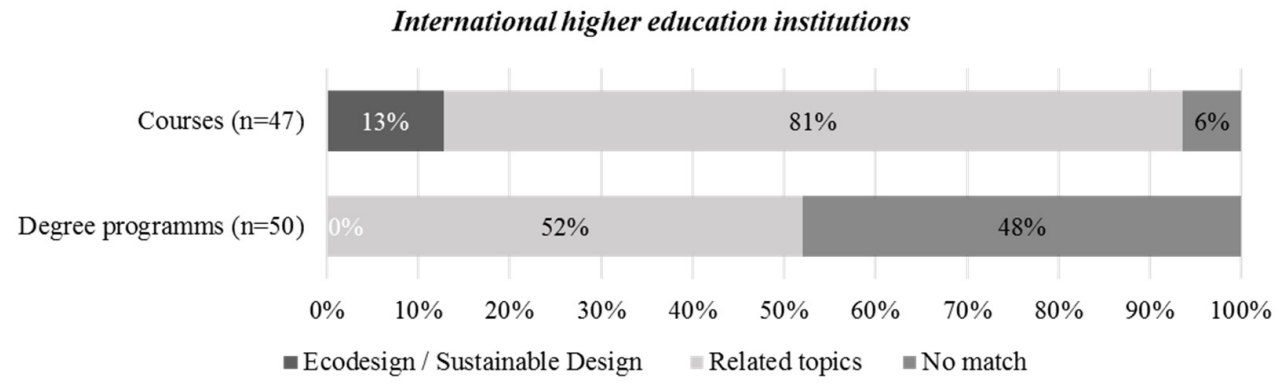

Figure 6. Analysis of international courses and degree programs 
Sustainability is a part of the engineering curricula of many higher education institutions around the world. Based on the above described analysis (see Figure 5 and 6), it can be concluded that Ecodesign or sustainable design are mostly taught along with adjacent topics and are only one of several subaspects of the general design theory or other environmentally related subjects. Some authors argue that specialised sustainability courses are needed, whereas others state that sustainability should be integrated into existing engineering courses and be an integral part of the curriculum (Olson et al., 2015). To ascertain the actual topics of the courses offered by the higher education institution presented, a further analysis has been conducted (see Section 4).

\section{Ecodesign and sustainable design content in higher education}

To identify which contents the green, sustainable or environmentally related engineering courses thematise and which life cycle phases they focus a further analysis has been carried out. In the following sections the literature research is described (Section 4.1), the generated results are explained with the aid of selected examples (Section 4.2), a preliminary conclusion is derived (Section 4.2) and the limits and boundaries of the analysis are discussed (Section 4.3).

\subsection{Material and method}

Similar to the first analysis, the module descriptions, handbooks and university websites of all 170 German and international higher education institutions were surveyed and manually analysed by the authors regarding their incorporation of sustainable, green, environmental or Ecodesign related content. In contrast to the analysis of the curricula of the universities in Section 3, here the total amount of courses (Ger. 356 and int. 148) were collected, organised and analysed based on the following categories of information: the title of the course, the detailed content, the learning targets and the addressed competences. To simplify the presentation of the results and to clarify the thematic focus, the identified courses were thematically clustered together (see first row in Table 1). Based on the description of the lifecycle phases in Section 2.2, the authors assessed which lifecycle phases (see first column in Table 1) the actual content of the grouped course topics covers or if it addresses a greater (societal) context beyond the product lifecycle. For the assessment, a distinction was made between full coverage (the focal phase of that course group), partial coverage (mention or thematization of the phase in the course group) and no coverage (no distinct reference to that phase in the course group). As an example, a course concentrating on the topic Ecodesign would mainly focus the product development (full coverage). But according to the definition of Ecodesign (see Section 2.1), it also addresses all other life cycle phases as well as a greater societal context (partial coverage).

\subsection{Results of the analysis}

The entire assessment of the thematic incorporation of life cycle phases within the course topics is presented in Table 1. Altogether 356 German courses (from 120 higher education institutions) and 148 international courses (from the 50 higher education institutions) could be clustered based on their content into thirteen major topics: Ethics, Sustainability, Environment; Sustainable product development, Ecodesign; Lightweight engineering; Alternative drive technology; Sustainable materials; Sustainable manufacturing; Recycling and Disposal; Sustainable transport; Energy efficiency; Environmental engineering and protection; Sustainable energies; Energy and climate management; Energy economy. The cluster sustainable manufacturing for example includes courses such as Energetic Optimisation in the Production (University of Stuttgart, Germany) and Introduction to Lean Manufacturing Systems (UC Berkeley, USA). These courses enable students to investigate manufacturing systems, in order to understand the production processes as well as efficiency technologies and to improve the overall production (UC Berkeley, 2017; Universität Stuttgart, 2017). Thus, the courses have their focus set in the manufacturing phase of the product lifecycle and also incorporate the process chain, product development, because competitive manufacturing systems are products that have to be developed and designed. The manufacturing phase chronologically follows the development (see Figure 1), so its content and processes have to be anticipated and determined during the development (see Table 1). 
Table 1. Assessment of course topics in relation to the product lifecycle

\begin{tabular}{|c|c|c|c|c|c|c|c|c|c|c|c|c|c|c|}
\hline \multirow{2}{*}{\multicolumn{2}{|c|}{$\begin{array}{l}\text { PLC } \\
\text { Categorisation } \\
\begin{array}{c}\text { Process chain Product } \\
\text { development }\end{array}\end{array}$}} & \multirow[t]{2}{*}{ 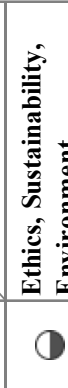 } & 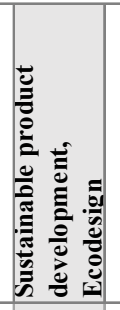 & 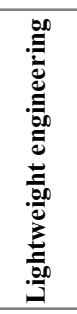 & \multirow{2}{*}{ 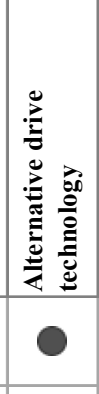 } & \multirow{2}{*}{ 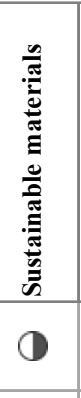 } & \multirow{2}{*}{ 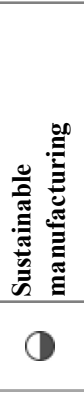 } & \multirow{2}{*}{ 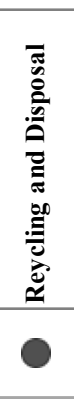 } & \multirow{2}{*}{ 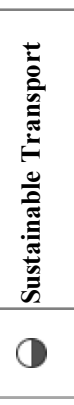 } & \multirow{2}{*}{ 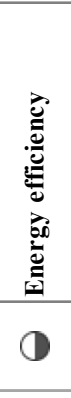 } & \multirow{2}{*}{ 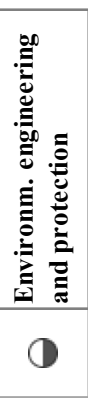 } & \multirow{2}{*}{ 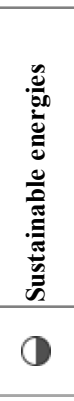 } & \multirow{2}{*}{ 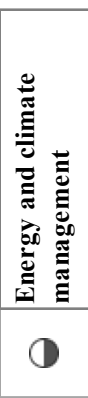 } & \multirow{2}{*}{ 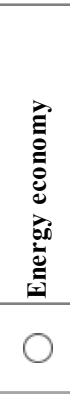 } \\
\hline & & & O & 0 & & & & & & & & & & \\
\hline \multirow{4}{*}{ 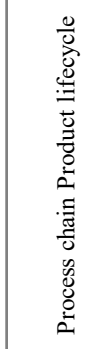 } & $\begin{array}{c}\text { Material } \\
\text { production }\end{array}$ & 0 & (1) & (1) & 0 & 0 & 0 & 0 & (1) & 0 & 0 & 0 & 0 & 0 \\
\hline & $\begin{array}{c}\text { Manu- } \\
\text { facturing }\end{array}$ & 0 & (1) & (1) & 0 & 0 & 0 & 0 & (1) & (1) & 0 & 0 & 0 & 0 \\
\hline & Usage & 0 & (1) & (1) & (1) & 0 & 0 & 0 & (1) & (1) & 0 & 0 & (1) & 0 \\
\hline & $\begin{array}{c}\text { Recycling } \\
\text { Disposal }\end{array}$ & O & (1) & 0 & O & 0 & 0 & 0 & (1) & (1) & ○ & 0 & 0 & 0 \\
\hline \multicolumn{2}{|c|}{ Greater context } & 0 & (1) & 0 & 0 & (1) & 0 & 0 & (1) & (1) & 0 & 0 & 0 & 0 \\
\hline \multirow{2}{*}{\multicolumn{2}{|c|}{$\begin{array}{l}\text { Total number of } \\
\text { German courses }\end{array}$}} & 6 & 10 & 60 & 15 & 1 & 23 & 21 & 0 & 29 & 54 & 76 & 27 & 34 \\
\hline & & $2 \%$ & $3 \%$ & $17 \%$ & $4 \%$ & $0 \%$ & $6 \%$ & $6 \%$ & $0 \%$ & $8 \%$ & $15 \%$ & $21 \%$ & $8 \%$ & $10 \%$ \\
\hline \multirow{2}{*}{\multicolumn{2}{|c|}{$\begin{array}{c}\text { Total number of } \\
\text { international courses }\end{array}$}} & 10 & 6 & 8 & 9 & 3 & 10 & 6 & 4 & 13 & 21 & 31 & 12 & 15 \\
\hline & & $7 \%$ & $4 \%$ & $5 \%$ & $6 \%$ & $2 \%$ & $7 \%$ & $4 \%$ & $3 \%$ & $9 \%$ & $14 \%$ & $21 \%$ & $8 \%$ & $10 \%$ \\
\hline
\end{tabular}

The topic Lightweight Engineering consist of courses such as Automotive lightweight construction Strategies, concepts and materials (Karlsruhe Institute of Technology, Germany), Development of lightweight products (Technical University Hamburg, Germany) and Lightweight construction (Swiss Federal Institute of Technology Zurich, Switzerland). The target of any lightweight construction is to minimize the weight without compromising the load capacity and other functions (safety, reliability, manufacturability, environment, recycling, etc.) (Ermanni, 2015). The primary focus of these courses lies in the product development and there are different lightweight principles for different phases within the development process. The application of lightweight principles and lighter materials is one way to reduce the weight of products and with that to save raw materials, cost and energy especially during the product's usage. To use less or alternative materials also affects the lifecycle phases material production and manufacturing (see Table 1).

The course group sustainable product development and Ecodesign, highlighted in grey, includes courses such as Sustainable product development - Blue Engineer Seminar, a master level course for the mechanical engineering degree (Technical University Berlin, Germany). The essential contents of the course are, inter alia, methods for the assessment of technology, social and ecologic responsibility of the engineering profession and the effects of technology on people and on the environment along the product lifecycle e.g. requirements or needs, material production, working conditions in the construction and production departments, recycling and the handling of waste (Meyer, 2017). So, this course targets all life cycle phases from development (its focus) to disposal as well as a greater societal context (see Table 1). Another lecture that belongs to this course group is called Development of sustainable products (Ecodesign), a mandatory course for the master degree in general mechanical engineering (University of Applied Sciences Frankfurt am Main, Germany). After the completion of the course, the students know and understand the difference between sustainability an innovation and can analyse and describe the product lifecycle of technical products with its energy and material flows. Furthermore, they are 
aware of the relevance of the usage phase and its effects on the environmental impacts and they know the potentials and challenges of the development of product-service systems (Fachhochschule Frankfurt am Main, 2014). So, this course also includes all life cycle phases (see Table 1) and even explicitly names the usage phase.

In summary, all product life cycle phases as well as the product development and the greater context are focussed of at least one course group, except for the usage phase, which is only partially covered by six course topics (see Table 1). Thus, the significance of the usage phase and its ecological potential are not yet extensively addressed in the curriculum of German and international higher education institutions. In most instances, the percentage of courses in one topic cluster offered by German and international institutions strongly resemble; however, some trends can be derived. The incorporation of societal topics into the general engineering education seems to have a lower importance in Germany, where only $2 \%$ of the courses address a higher, more comprehensive sustainable goal, compared to $7 \%$ of international courses in ethics, sustainability and environment (see Table 1). In Germany, traditional engineering topics still seem to be preferred, $17 \%$ of German and only $5 \%$ of international courses thematise lightweight engineering for example.

\subsection{Limitations of the analysis}

Obviously, numerous further international sustainable product development and Ecodesign course programs exist, that have not been mentioned here, because only the 50 best international higher education institutions for mechanical engineering were analysed. The technical University of Denmark for example pursues "the strategy of educating engineers [...] in sustainability through the development of a dedicated generic course on sustainability for all bachelor students (Olsen et al., 2015). In different countries sustainable courses are also not always taught at mechanical engineering faculties, but at other departments (e.g. civil engineering). Besides the investigated universities, the analysis is also limited by the specific courses that were examined. Some principles and themes that also influence the environmental impacts of a product during its lifetime and that have not been included in this research are for example courses covering product-service systems or circular economy.

The hypothesis that the instilled teaching content in higher education institutions eventually leads to an increased implementation of those topics in industry is taken as a basis for this analysis. The transfer problems of design methodologies from research into the industry are not part of this research. The didactic format of the analysed courses has also been neglected. Classical lectures are the leading teaching formats in engineering science. Even though most professors value practical construction projects for the impartment of constructive abilities, teacher-centric lectures will still dominate in the future (Albers et al., 2012). There is still not put enough emphasis on didactics and the way knowledge is imparted, especially in the field of engineering (Preißler et al., 2010).

\section{Conclusions}

Even though sustainable and environmentally related topics become significantly more important for companies, the application of Ecodesign is currently not an integral part of product development activities in the industry. One possible solution to close the gap is the sensitization of future engineers during their education even before they start to work in the industry. Within this publication it was analysed, whether German and international higher education institutions in the field of engineering meet these requirements and offer Ecodesign or sustainable design courses or degree programs. From 120 German higher education institutions only $9 \%$ offer courses and solely $2 \%$ offer degree programs that focus on Ecodesign or sustainable design. At least 13\% of the 50 international higher education institutions offer such courses, whereas no degree programs could be identified. German and international higher education institutions mostly address topics in their courses (Ger. 356 and int. 148) that somehow related to resource efficiency and the environment such as sustainable energies (Ger. 21\% and int. $21 \%$ of the courses), lightweight engineering (Ger. $17 \%$ and int. $5 \%$ of the courses) and environmental engineering and protection (Ger. 15\% and int. 14\%). All product life cycle phases from the development to the disposal are explicitly focused in the courses, except of the usage phase that was only partially covered by some of the courses. 
In conclusion, even though a small number of Ecodesign and sustainable design courses are already integrated in the curriculum of German and international higher education institutions, these topics are mostly indirectly addressed along with adjacent or related subjects and not directly imparted in separate courses. But to really contribute to a sustainable development, engineering students need to add sustainability to their paradigm and let it affect their everyday thinking (Holmberg et al., 2008). So, there is still a long way to go until Ecodesign and sustainable design are an integral part of the general engineering education and not just a mere "add-on". One way to foster this transformation for universities, is to release teaching materials and to share them with other educational institutions (e.g. via online-platforms). For this purpose, higher education institutions and its employees must improve their willingness to spread and share information and work closer together (e.g. in cross-national and interdisciplinary educational focus groups). In future analysis, it is necessary to enlarge the amount of international universities to be able to derive more valid results. It would also be interesting to examine the curricula country-specific and to identify best practices.

\section{References}

Abele, E., Anderl, R., Birkhofer, H. and Rüttinger, B. (2008), EcoDesign: Von der Theorie in die Praxis, SpringerVerlag Berlin Heidelberg, Berlin, Heidelberg.

Albers, A., Denkena, B. and Matthiesen, S. (2012), Faszination Konstruktion: Berufsbild und Tätigkeitsfeld im Wandel, arcatech STUDIE, Springer-Verlag, Berlin Heidelberg.

Allenby, B.R. (2009), "The Challenge of Sustainable Engineering Education”, Symposium on Engineering and Liberal Education, Union College, New York, June 5, 2009.

Blessing, L.T.M. and Chakrabarti, A. (2009), DRM, a Design Research Methodology, Springer, Dordrecht, New York. https://doi.org/10.1007/978-1-84882-587-1

Bohlken, J. (2017a), Hochschulen in Deutschland - Universitäten, eine Initiative des Profiling Institut Düsseldorf. [online] Bohlken Consulting. Available at: http://www.hochschulen-deutschland.org/fachhochschulen.html (accessed 11.06.2017).

Bohlken, J. (2017b), Hochschulen in Deutschland - Universitäten, eine Initiative des Profiling Institut Düsseldorf. [online] Bohlken Consulting. Available at: http://www.hochschulen-deutschland.org/universitaeten.html (accessed 11.06.2017).

Charter, M. and Tischner, U. (2001), Sustainable Solutions: Developing Products and Services for the Future, Greenleaf, Sheffield, U.K.

Dannheim, F. (1999), Die Entwicklung umweltgerechter Produkte im Spannungsfeld von Ökologie und Ökonomie: eine Analyse unter besonderer Berücksichtigung der Nutzungsphase Fortschritt-Berichte, VDIVerlag, Düsseldorf.

DIN EN ISO (2011), DIN EN ISO 14006:2011-10 Umweltmanagementsysteme - Leitlinien zur Berücksichtigung umweltverträglicher Produktgestaltung, ISO, Geneva, Switzerland.

Ermanni, P. (2015), Leichtbau: Skript zur Vorlesung 151-3207-00L. [online] ETH, Zürich. Available at: $\mathrm{http} / /$ www.structures.ethz.ch/content/dam/ethz/special-interest/mavt/design-materials-fabrication/compositematerials-dam/Education/Leichtbau/Script/Leichtbau_V1.0_20151211.pdf

Fachhochschule Frankfurt am Main (2014), Modulhandbuch Allgemeiner Maschinenbau. [online] FH FFM. Available at: https://www.frankfurt-university.de/fileadmin/de/Fachbereiche/FB2/Pr\% $\%$ C3\%BCfungsamt/ Modulhandbuecher/MHB_Ma_Maschinenbau_ASIIN_30.04.2014_pdf (accessed 12.05.2017).

Graulich, K., Brunn, C., Prieß, R., Quack, D., Scherf, C.-S. and Wolff, F. (2017), Ökologisches Design als Qualitätskriterium in Unternehmen stärken, Umweltbundesamt.

Grüner, C. (2001), Die strategiebasierte Entwicklung umweltgerechter Produkte, PhD thesis, TU Darmstadt.

Holmberg, J., Svanström, M., Peet, D.-J., Mulder, K., Ferrer-Balas, D. and Segalàs, J. (2008), "Embedding Sustainability in Higher Education through Interaction with lecturers: Case studies from three European technical universities", European Journal of Engineering Education, Vol. 33 No. 3, pp. 271-282. https://doi.org/10.1080/03043790802088491

Johansson, G. (2002), "Success factors for integration of ecodesign in product development", Environmental Management and Health, Vol. 13 No. 1, pp. 98-107. https://doi.org/10.1108/09566160210417868

Karlsson, R. and Luttropp, C. (2006), "EcoDesign: what's happening? An overview of the subject area of EcoDesign and of the papers in this special issue", Journal of Cleaner Production, Vol. 14 No. 15-16, pp. 1291-1298. https://doi.org/10.1016/j.jclepro.2005.11.010

Ma, J., Yin, F., Liu, Z. and Zhou, X. (2012), "The Eco-design and Green Manufacturing of a Refrigerator", Procedia Environmental Sciences, Vol. 16, pp. 522-529. https://doi.org/10.1016/j.proenv.2012.10.072 
Meyer, H. (2017), Nachhaltige Produktentwicklung - Blue Engineer Seminar. [online] TU Berlin. Available at: https://moseskonto.tu-berlin.de/moses/modultransfersystem/bolognamodule/ansehen.html?number=50459 (accessed 12.05.2017).

Oberender, C. (2006), Die Nutzungsphase und ihre Bedeutung für die Entwicklung umweltgerechter Produkte, $\mathrm{PhD}$ thesis, TU Darmstadt.

Olsen, S.I., Nielsen, S.B., Ejlertsen, M.L. and McAloone, T. (2015), "Teaching sustainable solutions in engineering”, International Journal of Innovation and Sustainable Development (IJISD), Vol. 9 No. 2, pp. 157167. https://doi.org/10.1504/IJISD.2015.068788

Pigosso, D.C.A. and Leroy, Y. (2017), Follow up from workshop. ICED 2017. Georgia Tech; BTH; DTU; the Design Society, 01.11.2017.

Preißler, I., Hammerschmidt, J., Müller, R. and Scholl, S. (2010), "Hochschuldidaktik trifft Ingenieursausbildung: Segen oder Fluch?”, Didaktik der Physik, Hannover, Germany, March 08 - 12.

Quacquarelli Symongs Limited (2016), QS World University Rankings by Subject 2016 - Engineering Mechanical, Aeronautical \& Manufacturing. [online] Available at: https://www.topuniversities.com/university-rankings/university-subject-rankings/2016/engineeringmechanical (accessed 08.11.2017).

Ropohl, G. (2009), Allgemeine Technologie: Eine Systemtheorie der Technik.

Ruedenauer, I. (2006), Kühl- und Gefriergeräte als EcoTopTen-Produkte, Öko-Institut e.V., Freiburg.

Schäfer, P. and Apostolov, H. (2014), "Nachhaltige Produktentwicklung”, In; Eigner, M., Roubanov, D. and Zafirov, R. (Eds.), Modellbasierte Virtuelle Produktentwicklung, Springer Vieweg, Berlin, Heidelberg, pp. 369-392. https://doi.org/10.1007/978-3-662-43816-9_16

The European Parliament and the Council of the European Union (2009), "Directive 2009/125/EC of the European Parliament and of the Council of 21 October 2009 establishing a framework for the setting of ecodesign requirements for energy-related products", Official Journal of the European Union, Vol. 52, pp. 10-35.

UC Berkeley (2017), Berkeley Academic Guide 2017-18. [online] UC Berkeley. Available at: http://guide.berkeley.edu/undergraduate/degree-programs/mechanical-engineering/\#coursestext (accessed 05.12.2017).

United Nations (1987), Report of the World Commission on Environment and Development, Our Common Future.

Universität Stuttgart (2017), Aktuelle Lehrveranstaltungen des EEP. [online] Universität Stuttgart. Available at: http://www.eep.uni-stuttgart.de/lehre/Vorlesungen/ (accessed 05.12.2017).

VDI (1993), VDI 2221 - Methodik zum Entwickeln und Konstruieren technischer Systeme und Produkte, Verein Deutscher Ingenieure.

Verhulst, E. and van Doorsselaer, K. (2015), "Development of a hands-on toolkit to support integration of ecodesign in engineering programmes", Journal of Cleaner Production, Vol. 108, pp.772-783. https://doi.org/10.1016/j.jclepro.2015.06.083

Daniela Kattwinkel, Research assistant

Ruhr-Universität Bochum, Product Development

Universitaetsstr. 150, 44801 Bochum, Germany

Email: kattwinkel@1pe.rub.de 